\title{
Clinical and surgical therapeutic approach in Erithema Elevatum Diutinum - Case report ${ }^{*}$ Abordagem terapêutica clínico-cirúrgica no Eritema Elevatum Diutinum - Relato de caso
}

\author{
Luciana Helena Zacaron ${ }^{1}$ \\ Vanessa Maria Amoreira Curty ${ }^{3}$ \\ Ricardo Barbosa Lima ${ }^{5}$
}

\author{
Júlia Costa de Faria Gonçalves² \\ Antonio Macedo D' Acri $^{4}$ \\ Carlos José Martins ${ }^{6}$
}

\begin{abstract}
Erythema elevatum diutinum is a rare chronic cutaneous vasculitis which usually affects adults. It is characterized by symmetrical and persistent papules, plaques, and nodules. These lesions are usually located on the extensor surfaces of the extremities. We report a case of erythema elevatum diutinum in which the association of dapsone and surgical excision promoted complete remission of skin lesions, providing a new approach to the treatments described in the literature.
\end{abstract}

Keywords: Dapsone; Erythema; Vasculitis

Resumo: O eritema elevatum diutinum é uma vasculite cutânea rara, crônica, que costuma afetar adultos, manifestando-se com pápulas, placas e nódulos, simétricos e persistentes, nas regiões extensoras das extremidades. Relata-se um caso de eritema elevatum diutinum, onde a associação terapêutica da dapsona e excisão cirúrgica promoveu a remissão completa das lesões cutâneas, oferecendo uma nova abordagem aos tratamentos descritos na literatura.

Palavras-chave:Dapsona; Eritema; Vasculite

\section{INTRODUCTION}

Erythema elevatum diutinum (EED) is a distinct form of cutaneous vasculitis, since its peculiar clinical pattern, associated with the chronicity of the process, is unique. ${ }^{1}$ After the description of the disease by Hutchinson in 1878, Radclife-Crocker and Williams, in 1894, proposed the current nomenclature, based on its clinical characteristics. ${ }^{2}$ Its pathogenesis remains unknown, but it is believed that infections or repeated antigenic stimuli provoke the deposition of immune complexes in vessel walls. ${ }^{3}$ Its association with hematological, autoimmune, neoplastic and infectious diseases is common. Clinically, it is characterized by symmetrical and persistent papules, plaques, and nodules located on the extensor surfaces of the extremities. ${ }^{4}$

Received on 22.09.2012.

Approved by the Advisory Board and accepted for publication on 03.11.2012

Work conducted at the Dermatology Service of Hospital Universitário Gaffrée e Guinle (HUGG) - Federal University of the State of Rio de Janeiro (Universidade Federal do Estado do Rio de Janeiro - UNIRIO) - Rio de Janeiro (RJ), Brazil.

Financial Support: None

Conflict of Interest: None.

Medical Residency in Anatomic Pathology, Hospital Universitario Antonio Pedro - Universidade Federal Fluminense (HUAP-UFF) - Graduate student of the Dermatology Service, Hospital Universitário Gaffrée e Guinle, Federal University of the State of Rio de Janeiro (HUGG-UNIRIO) - Rio de Janeiro (RJ), Brazil. Graduate Degree in Dermatology, Dermatology Service, Hospital Universitário Gaffrée e Guinle, Federal University of the State of Rio de Janeiro (HUGGUNIRIO) - Rio de Janeiro (RJ), Brazil.

Degree in Medicine, Federal University of the State of Rio de Janeiro (UNIRIO) - Graduate student of the Dermatology Service, Hospital Universitário Gaffrée e Guinle, Federal University of the State of Rio de Janeiro (HUGG-UNIRIO) - Rio de Janeiro ( RJ), Brazil.

$\mathrm{PhD}$ in Dermatology, Federal University of Rio de Janeiro (UFRJ) - Professor at the Dermatology Service, Hospital Universitário Gaffrée e Guinle, Federal University of the State of Rio de Janeiro (HUGG-UNIRIO) - Rio de Janeiro (RJ), Brazil.

Graduate Degree in Dermatology, Dermatology Service, Hospital Universitário Gaffrée e Guinle, Federal University of the State of Rio de Janeiro (HUGGUNIRIO) - Professor at the Dermatology Service, Hospital Universitário Gaffrée e Guinle, Federal University of the State of Rio de Janeiro (HUGG-UNIRIO) - Rio de Janeiro (RJ), Brazil.

6 MSc, Federal University of the State of Rio de Janeiro (UNIRIO) - Professor and Head of the Dermatology Service, Hospital Universitário Gaffrée e Guinle, Federal University of the State of Rio de Janeiro (HUGG-UNIRIO) - Rio de Janeiro (RJ ), Brazil. 


\section{CASE REPORT}

Male patient, 56 years old, white, 18 months ago reported the development of soft and ulcerated erythematous papules on his hands, which when squeezed, eliminated purulent exudate. He also presented with nodular lesions on his elbows. Physical examination revealed yellowish, hardened erythematous nodules on the extensor surface of his elbows, measuring $1.7 \mathrm{~cm}$ in the right elbow and $3.5 \mathrm{~cm}$ in the left elbow (Figure 1). On the dorsal surface of his right hand, linear papular-nodular lesions were observed (Figure 2) and in the palmar region, there were numerous small ulcerations with purulent exudate (Figure 3). Histopathological examination of the biopsy of the nodule on his right elbow revealed irregular acanthosis, extensive fibrosis in the reticular dermis, interspersed with lymphohistiocytic inflammatory infiltrate and focal areas of neutrophils with leukocytoclasia (Figure 4). Culture of the purulent exudate showed no growth of microorganisms. The clinical and histopathological correlation led to the diagnosis of EED, late stage. Due to the frequent association with systemic diseases, laboratory and radiological exams (complete blood count with differential and platelet count, BUN, creatinine, liver function tests, ESR, C-reactive protein, RF, ASO, ANA, ANCA, protein electrophoresis, G6PD, VDRL, Fta-Abs, serology for viral hepatitis and HIV, tuberculin test, hands and chest radiographs, urinalysis and $24 \mathrm{~h}$ urine) were carried out, without any changes.

Treatment with dapsone $100 \mathrm{mg} /$ day was initiated, and the palmar ulcerations healed. After 4 months, the dose was reduced to $50 \mathrm{mg} /$ day. As the nodules in the elbows did not heal, five sessions of infiltrations with dexamethasone $10 \mathrm{mg} / \mathrm{ml}, 2 \mathrm{ml}$ in each nodule, were performed every fifteen days. However, the nodules on the elbows persisted, bothering the patient while he performed his usual activities, so we opted for the surgical excision of the nodules with excellent results (Figure 5). One year after the surgery, the patient continued to use dapsone $50 \mathrm{mg} /$ day, without the development of new lesions.

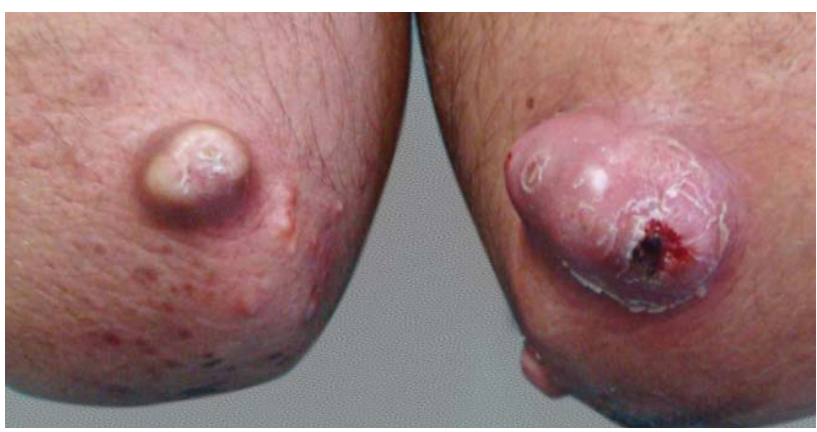

FIGURE 1: Hardened, yellowish erythematous nodules on the extensor surface of the elbows

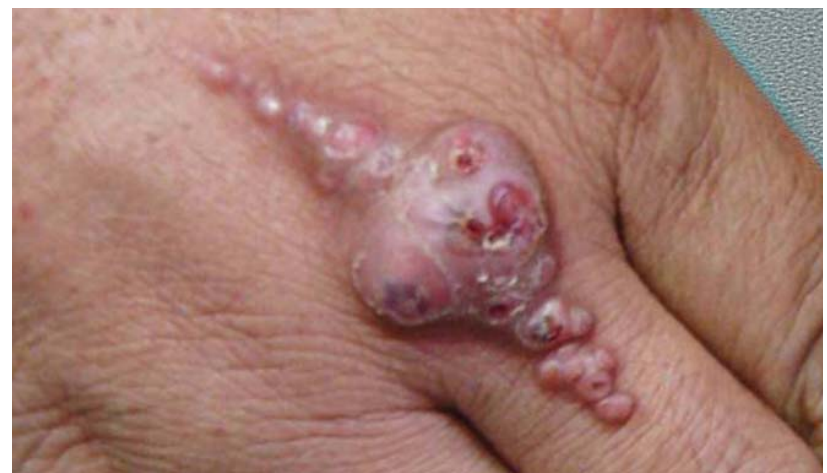

FIGURE 2: Linear papular-nodular lesions on the dorsal surface of the right hand

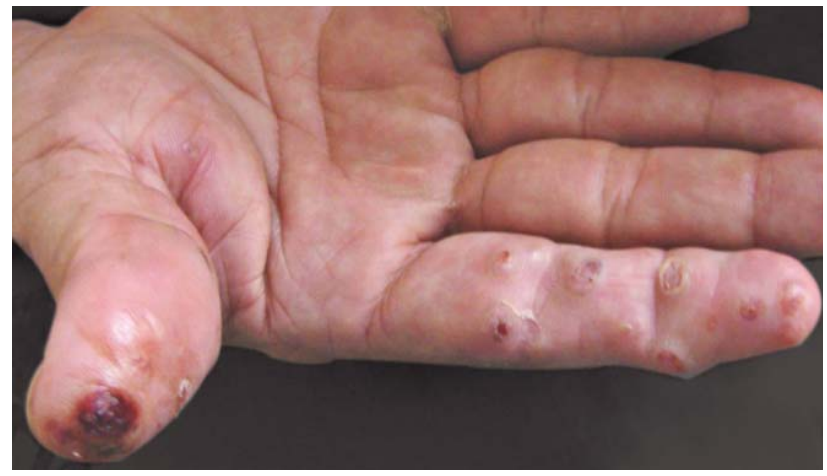

Figure 3: Palmar aspect of the right thumb and forefinger showing numerous small ulcerations with purulent exudate

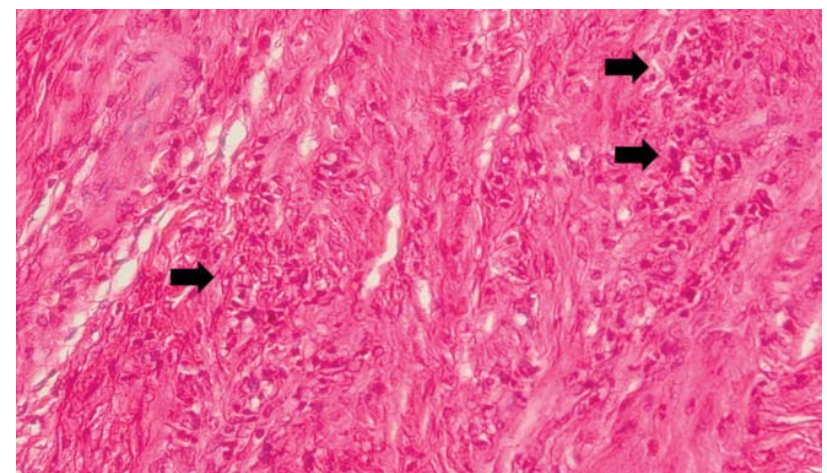

FIGURE 4: Fibrosis in the reticular dermis, interspersed with lymphohistiocytic inflammatory infiltrate and focal areas of neutrophils with leukocytoclasia (arrows), HE 200x

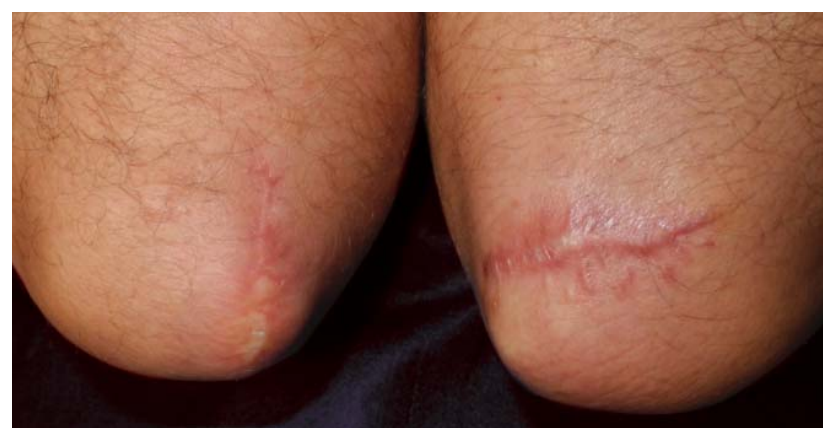

FIGURE 5: Results 1 year after surgical excision of the nodule on the right elbow and 4 months after excision of the nodule on the left elbow 


\section{DISCUSSION}

EED is a rare cutaneous vasculitis that often affects adults aged 40-60 years, with a slight male predominance. Although the etiology of the disease is unknown, it is related to the deposit of immune complexes on the wall of post-capillary venules, activation of the complement cascade, and neutrophil chemotaxis, releasing lisoenzimes, collagenase, myeloperoxidase and hydrolases that induce fibrin deposits in and around the capillaries and venules. ${ }^{5,6}$ The lesions consist mainly of persistent and symmetrical erythematous papules, plaques and nodules, mainly located on the extensor areas of the extremities. They are initially soft and erythematous purpuric, with occasional blisters and ulcers. They evolve as hardened, erythematous, yellowish or brownish nodules, leaving a hypo-or hyperpigmented atrophic surface as they regress. In general, the disease is asymptomatic, but it may be accompanied by joint pain and lesions can be painful, with a local burning sensation. ${ }^{7}$

There are several differential diagnoses to be considered. In the early stage of the disease, they include Sweet's syndrome, pyoderma gangrenosum, facial granuloma, drug-induced rash, erythema multiforme, bullous pemphigoid, and porphyria cutanea tarda. In its late stage, dermatofibroma, fibromatosis, bacillary angiomatosis, Kaposi's sarcoma, xanthomas and necrobiotic xanthogranuloma. ${ }^{7}$

Diagnosis is made by clinical and histopathological correlation. Leukocytoclastic vasculitis is observed in the dermis in the early stage of the disease, and granulation tissue, fibrosis, vascular proliferation, lymphohistiocytic inflammatory infiltrate and focal areas of neutrophils with leukocytoclasia are seen in its late stage, as observed in our patient. ${ }^{8}$

EED can be associated with hematologic systemic diseases (IgA paraproteinemia, multiple myelo- ma and myelodysplasia), autoimmune diseases (rheumatoid arthritis, systemic lupus erythematosus and inflammatory bowel disease), solid tumors (prostate cancer), and even bacterial and viral diseases (streptococcal infections, HIV, syphilis and hepatitis). As there is no direct relationship between systemic diseases and EED, Gibson et al., in 2005, suggested the term co-occurrence rather than association, although they emphasize the importance of investigating systemic diseases because of their high prevalence in cases of EED., ${ }^{, 9}$

Treatment aims to relieve the discomfort caused by the lesions, reduce skin damage and eradicate or minimize systemic diseases, when present. Earlystage lesions respond to dapsone, 50 to $200 \mathrm{mg}$ / day. This drug inhibits neutrophil chemotaxis and complement deposition on the vessel wall, with a suppressive but not curative effect, with risk of relapse after discontinuation of the drug. Other therapeutic options are colchicine, tetracycline, niacinamide and systemic steroids, with varying results. ${ }^{1}$ In late-stage lesions, fibrosis predominates, with little response to dapsone, as in the case reported. Intralesional corticosteroid can be used to treat these lesions. ${ }^{1}$ In 2010, Rinard et al. showed the effectiveness of surgical treatment in a patient with multiple nodules in the hands, elbows and knees, which were successively excised, alleviating local discomfort. ${ }^{10}$

This case highlights the importance of combining therapeutic methods to benefit the patient, associating the good response of acute lesions to dapsone with the use of intralesional corticosteroids and surgical excision to treat late-stage lesions. Surgical excision is a treatment option that has been recently described and has shown excellent results. $\square$ 


\section{REFERENCES}

1. Comfere NI, Gibson LE. Erythema Elevatum Diutinum. In: Wolff K, Goldsmith LA, Katz SI, Gilchrest BA, Paller AS, Leffell DJ, editors. Fitzpatrick's Dermatology General Medicine. New York: McGraw-Hill; 2008. p. 1616-9.

2. Antonio JR, Antonio CR, Balau JP, Miguel D, d'Ávila SCGP. Erythema elevatum diutinum: a case report and review of the literature. An Bras Dermatol. 2002;77:481-7.

3. Hatzitolios A, Tzellos TG, Savopoulos C, Tzalokostas V, Kaiafa G, Psomas E, et al. Erythema elevatum diutinum with rare distribution as a first clinical sign of nonHodigkin's lymphoma: a novel association? J Dermatol. 2008;35:297-300.

4. Smitha P, Sathish P, Mohan K, Sripathi H, Sachi G. A case of extensive erosive and bullous erythema elevatum diutinum in a patient diagnosed with human immunodeficiency virus (HIV). Int J Dermatol. 2011;50:989-91.

5. Ziemer M, Koehler MJ, Weyers W. Erythema elevatum diutinum - a chronic leukocytoclastic vasculitis microscopically indistinguishable from granuloma faciale. J Cutan Pathol. 2011;38:876-83.

6. Muratori S, Carrera C, Gorani A, Alessi E.. Erythema elevatum diutinum and HIV infection: a report of five cases. Br J Dermatol. 1999;141:335-8.

7. Gibson LE, El-Azhary RA. Erythema elevatum diutinum. Clin Dermatol. 2000;18:295-9.

8. Wikinson SM, English JS, Smith NP, Wilson-Jones E, Winkelmann RK.. Erythema elevatum diutimum: a clinicopathological study. Clin Exp Dermatol. 1992;17:87-93.

9. Wahl CE, Bouldin MB, Gibson LE. Erythema elevatum diutinum: Clinical, histopathologic and imuhistochemical characteristic of six patients. Am J Dermatopathol. 2005;27:397-400.

10. Rinard JR, Mahabir RC, Greene JF, Grothaus P. Successful surgical treatment of advanced erythema elevatum diutinum. Can J Plast Surg. 2010;18:28-30.

\author{
MAILING ADDRESS: \\ Luciana Helena Zacaron \\ Rua Mariz e Barros, 775 \\ 20270-004 - Rio de Janeiro - RJ \\ Brazil \\ E-mail:lh.zacaron@uol.com.br
}

How to cite this article: Zacaron LH, Gonçalves JCF, Curty VMC, D'Acri, AM, Lima RB, Martins CJ. Clinical and surgical therapeutic approach to treat Erithema Elevatum Diutinum: case report. An Bras Dermatol. 2013;88(6 Suppl 1):S15-8. 